from his observations on marine currents, and was discovered by him in 1930. The recent party found that it was half as large again as was shown on existing maps.

\title{
SPECIAL WORKING CONDITIONS IN THE FAR NORTH
}

\section{OF THE U.S.S.R.}

[Summarised from the text of instructions issued by the People's Commissariat of Finance and the All-Union Central Committee of Trade Unions on the application of the Decree of the Presidium of the Supreme Soviet of the U.S.S.R., dated 1 August 1945: "On Privileges for Persons Working in Regions of the Far North; Vedomasti Verhounogo Soveta (Moscow) 20 August 1945, and Sobraniye Postanovlenii $i$ Rasporyazhenii Pravitelstva S.S.S.R. (Moscow), No. 9,31 October 1945 ; No. 10, 30 October 194.5.]

There have recently been awarded special privileges for certain categories of people working in the Far North of the U.S.S.R. The term "Far North" includes all islands in the Arctic Ocean and adjacent seas, besides specified areas of the mainland. The privileges are in the form of increased pay (a $10 \%$ bonus on basic rates), increased leave and free return travel for the worker, and certain facilities for his family. In the calculation of pension rights one year's service in the Far North is to count as two years elsewhere. Leave may be accumulated for three years but may not exceed six months total, including one month's travelling time. Accumulated leave beyond six months and any other leave not actually taken, will be compensated by additional pay.

The purpose of the awards is presumed to be some compensation for the enforced isolation and for the severity of conditions. It is not clear, however, whether the awards are intended to attract labour to these new pioneer areas, or are designed primarily to mitigate conditions for members of the various classes of directed labour which are listed. The privileges are not available for those directed to work in the Far North for periods of less than a year, nor for those recruited locally, nor for those under sentence.

Since the inception of the scheme further areas have been defined in which privileges are applicable but with lower percentage benefits and lesser periods of leave.

\section{THE KURIL ISLANDS (CHISHIMA)}

In a broadcast speech of 2 September 1945, Marshal Stalin stated that the Kuril Islands and Southern Sakhalin would pass to the Soviet Union to serve "not as a means of isolating the Soviet Union from the ocean and as a base for a Japanese attack on our Far East, but as a means of direct communication for the Soviet Union with the ocean and as a base for the defence of our country against Japanese aggression". This constituted the first announcement of the terms of the secret agreement reached at the Yalta Conference on 11 February 1945, which were subsequently published as a White Paper on 11 February $1946 .{ }^{1}$

1 Agreement concerning the Entry of the Soviet Union into the war against Japan. Miscellaneous No. 4 (1946). Cmd. 6735. H.M. Stationery Office, London. 
The sections dealing with these Japanese sub-Arctic territories read as follows: "The southern part of Sakhalin as well as all the islands adjacent to it shall be returned to the Soviet Union", and "the Kuril Islands shall be handed over to the Soviet Union". These transfers of territory were agreed upon by Marshal Stalin, President Roosevelt and Mr Churchill; they were to take effect as a condition of the entry of the Soviet Union into the war against Japan and were to be "unquestionably fulfilled after Japan has been defeated".

The Kuril Islands, called Chishima by the Japanese, stretch in a northeasterly direction, from Nemuro Bay, at the extreme east of Hokkaido, to the southernmost point of Kamchatka, a distance of some $\mathbf{7 0 0}$ miles. There are $\mathbf{3 2}$ of them, with a total area of 6159 square miles; only four, however, are of great size, namely, Kunashiri, Etorofu, Urup and Paramushiro. From Notsu Cape, in Hokkaido, to Tomari, the most westerly point in Kunashiri, is about $7 \frac{1}{2}$ miles, and the distance is about the same between Shumushu, most northerly of the Kurils, and Kamchatka. The Kurils are rugged and extremely volcanic, their name being derived from the Russian kurit, to smoke. The chief port of Kunashiri is Tomari, on the south coast. Etorofu, the principal island of the group, is divided into four provinces for administrative purposes. It has a coastline broken by deep bays, of which the largest are Naibo, Rubetsu, and Bettobu on the northern coast and Shikotap on the southern. It has three ports, Shana, Rubetsu and Shibetoro, all on the northern coast. Shana is the largest.

The first European to sight the islands was the Dutch navigator, Martin de Vries, in 1643. According to a Japanese source, ${ }^{1}$ it was supposed until recently that the earliest Japanese record of Chishima dated from 1786, but in 1941 it was discovered that a territorial registry compiled in 1700 by the feudal lord of Matsumai, who was entrusted with the rule of Hokkaido, included not only Chishima up to Shumushu, but even a piece of Kamchatka. This, however, - even if true, represents a purely theoretical claim, based on visits by Japanese fishing craft. It is more than probable that the inhabitants of these northern areas, although entered as Japanese in the official records, were, in reality, Ainus. Towards the end of the eighteenth century the Japanese did establish some small settlements on Etorofu and Urup. Meanwhile, in 1711, the Russians had appeared in Chishima and from that time onwards remained virtually in possession of the islands. In 1838 the Daimyo of Mito made a representation to the Shogun pointing out the increasing encroachment of Russia upon the islands and asking that they be taken from the incapable Matsumai lord and transferred to Mito jurisdiction. Nothing came of this and the Kurils remained in the hands of the Russians until 1875, when the question of rival Russian and Japanese claims in Sakhalin and the Kurils was settled by a Convention under which Japan withdrew from Sakhalin in favour of Russia and the latter power abandoned the Kurils to Japan. The Japanese Government made the Kurils a part of the Prefecture of Nemuro in Hokkaido, and divided them into eight subPrefectures.

1 Quoted in Japan Times and Advertiser, 23 June 1941. 
As a result of the Russo-Japanese War of 1904-05, Russia ceded the southern half of Sakhalin to Japan.

Until recent years the Kurils were neglected by the Japanese Government. In 1893 Lieutenant Naritada Gunji, a retired naval officer, went with a small number of men to Shimushu and established a defence post there. This northernmost island of Chishima contains a monument commemorating his achievement, which.was as successful as a voluntary affair of this kind could expect to be. The Government remained indifferent to the islands until 1932, after the visit of Colonel Lindbergh on his round-the-world flight. Then the Sanyo Maru, a 217-ton steamer, was sent from Nemuro to explore the bays and harbour possibilities and to examine the fishery prospects. In consequence of this expedition salmon and trout fisheries began to develop and have grown rapidly. The Chishima fisheries began much later than those farther north around Kamchatka, which grew up after the Treaty of Portsmouth in 1905. In 1937 the annual catch of the Chishima fisheries amounted to some 50 million yen, and some 20,000 fishermen and labourers now go there annually during the fishing season.

During the Okada Ministry (1934-36) two million yen were spent in the construction of a harbour in a bay recently formed by volcanic action at Kakumabetsu on Paramushiro. Under the same Ministry a lighthouse was erected on Shimushu and a meteorological observatory near Kakumabetsu. Three years later a second exploring party, headed by Mr Tadaatsu Ishiguro, was sent out by the Hokkaido local authorities to survey the industrial possibilities of the Kurils. The expedition was due to conclude its work during 1941. Also in 1941 a scientific expedition was sent out under the auspices of the newspaper Asahi, but their schooner, the Koryu Maru, was wrecked on 13 June near Urup.

Within the last decade the Kuril Islands have become of increasing strategic importance. They extend across the main entrance to the Sea of Okhotsk and form a barrier between the United States and the Soviet North Pacific coast. They extend towards the Aleutian Islands; the distance from Paramushiro to Attu is some $\mathbf{7 6 0}$ miles, and to Amchitka a further 200. During the recent war the Japanese established naval and air bases on Paramushiro and Shumushu, and it was probably from these that the Japanese despatched the expedition which occupied Attu and Kiska in 1942.

Ships going to Vladivostok-or to the more northerly port of Nikolaevsk at the mouth of the Amur, whence there is river and motor transport to the Trans-Siberian railway at Khabarovsk-can use one of four routes without passing within three miles of the land:

(1) Round the south of Japan and through the Tsushima Strait between Japan and Korea;

(2) Through the Tsugaru Strait between Honshu, the main island of Japan, and Hokkaido;

(3) Through the Soya Strait between Hokkaido and Karafuto (the southern half of Sakhalin);

(4) Through one of the straits between the islands of the Kuril chain (or 
within Soviet territorial waters round the southern end of Kamchatka, across the Okhotsk Sea and round the northern end of Sakhalin).

The first three of these routes involve passing through fairly narrow straitsthe Tsushima Strait is much the largest in total width, but has the two islands of Tsushima and Iki in the middle, breaking it up into three channels. The Tsugaru Strait, with a width of twelve miles, is the most convenient for ships approaching the Japan Sea from the east.

The route to the north of the Kurils and Sakhalin is much longer than the other three and is more difficult for traffic in winter owing to the conditions of navigation in the Okhotsk Sea and Tatarsky Strait (between Sakhalin and the Siberian mainland). Even at Vladivostok the harbour has to be kept open with ice-breakers in winter, but shipping has only to cope with ice on approaching the coast. The Okhotsk Sea, on the other hand, is infested with floating ice for half the year, especially in the area north of Sakhalin. Tatarsky Strait is entirely frozen and is crossed by sledge traffic from the mainland to Sakhalin for three months in each year.

BRIA N R OBERTS

\section{PROTOCOL OF THE EAST GREENLAND TREATY OF 9 JULY 1924}

On 24 August 1945 the Danish Rigsdag ratified a Protocol signed in Copenhagen on 18 July 1945 between Denmark and Norway relating to an alteration in the conditions governing the termination of the East Greenland Treaty of 9 July 1924 between Denmark and Norway. A translation of the text of the Protocol is given below:

"The Royal Danish Government and the Royal Norwegian Government have agreed as follows:

According to the terms of Article 9 of the East Greenland Treaty of 9th July, 1924 between Denmark and Norway, which reads as follows:

'This Treaty shall come into force on July 10th 1924 and shall be irrevocable for twenty years with an extension for a similar period, provided it is not denounced by either of the parties not less than two years before the expiry of the twenty years period',

the period during which it could be denounced expired on July 10th 1942 .

In 1942, it was agreed between the two Governments that the provisions of Article 9 of the Treaty could not operate so long as Denmark and Norway were militarily occupied, and that therefore both parties should retain the right to denounce the Treaty with due observance to two years notice, provided that notice was given within a reasonable period after both countries had regained their freedom.

It has now been agreed that the term of notice defined in Article 9 shall expire on July 10th 1946, and the Treaty remain in force provided it is not terminated by one of the parties giving two years notice before the last mentioned date to terminate it on July 10 th 1948 . 